\title{
The Influence of Realistic Mathematic Approach to Student Achievement of Elementary School
}

\author{
$1^{\text {st }}$ Sony Irianto, $2^{\text {nd }}$ Subuh Anggoro, $3^{\text {rd }}$ Ana Andriani, $4^{\text {th }}$ Annisa Luthfiani \\ \{ sonyirianto75@gmail.com¹, subuhanggoro@ump.ac.id² ana.andriani@gmail.com³, \\ annisaluth835@gmail.com $\left.{ }^{4}\right\}$ \\ ${ }^{1,4}$ Pendidikan Guru Sekolah Dasar, Universitas Muhammadiyah Purwokerto \\ 2,3 Magister Pendidikan Dasar, Universitas Muhammadiyah Purwokerto
}

\begin{abstract}
The purpose of this study was to determine the impact of a realistic mathematics approach on students' learning achievement in the fourth grade of primary school. The quasi-experimental research design with nonequivalent Control Group Design was used in this study. The samples for this study were 42 fourth graders from SD Negeri Karangnangka who were drawn from two classes: 20 students from Class IVA (experiment group) and 22 students from Class IVB (control group) using cluster random sampling. Students' learning achievement data were collected using a pretest and a posttest. The findings revealed a link between a realistic mathematics approach and student learning. achievement.
\end{abstract}

Keywords: realistic mathematics approach, learning achievement, elementary school

\section{Introduction}

The lack of strength in the learning process is the one of the educational problems. Students gain a lot of knowledge in class activities designed to improve students' ability to memorize information, but they would not look for evidence themselves, rather than just sitting for the teacher's communication of ideas, so knowledge is not implemented in everyday life and will be forgotten even faster [1-2]. If rote learning and procedural skills are not practiced, knowledge gained through deep understanding may be overlooked [3-4].

Elementary school students perceive mathematics to be difficult and frightening. Mathematics is widely regarded as a difficult subject because it is both a formula memorizing science and an abstract science unrelated to reality. This student perspective is accompanied by the teacher's method of delivering mathematics lessons, which is frightening, does not attract attention, and thus results in low mathematics learning achievement [2][5-6].

RME approach employs the scientific method [7-9]. Scientists use it to discover new facts or theories. [10-11]. Scientists used this method to feature supports or new theories, and scientists were expected to think creatively [12-13]. Because the facts or theories of a scientist cannot be discovered using only low-order thinking skills [7][9][14]. As a result, students are low stimulated to improve their critical thinking skills while learning [15-16]. 
The improving of student memorize information can be used in-class activities [17]. A lack of strength in the learning process is the education problems. So, the students are less motivated to improve their thinking abilities [18-20]. Activities in class aimed at improving students' strengthening to memorize information. Students may have much of knowledge, but they don't seek it out; they just watch out for the lesson introduced by the educator, As a result, knowledge is rarely applied in real life and is rarely forgotten. [17][21-22]. They contended that rote learning and if not exercised, procedural knowledge, result in knowledge that is easily overlooked when compared to knowledge trough obtained better understanding.

Arnellis et al. found that a realistic mathematics education approach influenced high school students' calculus learning achievement [23]. The purpose of this study is to see how it affects elementary school student achievement.

\section{Method}

The study was carried out in the fourth grade at SD Negeri Karangnangka in Kedungbanteng District, Banyumas Regency. This quantitative study employs the quasiexperimental method and the Nonequivalent Control Group Design.

The population of this study included all 42 students in grade IV SD Negeri Karangnangka. This study's sample included 20 grade IV students from class IVA and 22 from class IVB. In this study, cluster random sampling was used for sampling. The method of gathering data on mathematics learning achievement before and after treatment by administering tests before and after treatment.

Prior to testing, the research instrument performed item analysis. To validate the test instrument, the validity test with the product moment formula was used. The Cronbach Alpha formula is used to determine dependability. The test results demonstrate that the items to be used are both valid and reliable.

Students' posttest scores in the experimental and control groups were compared. To determine the difference in fourth grade SD learning achievement using a realistic mathematical approach to the experimental group and a scientific approach to the control group. State of Karangnangka, The following data processing steps are used: normality test using chi-squared, homogeneity test using $\mathrm{F}$ test, hypothesis testing (t-test) with manual calculations, and data analysis.

\section{Result and Discussion}


Table 1. Tests of Normality Result

\begin{tabular}{llllllll}
\hline & & \multicolumn{3}{l}{ Kolmogorov-Smirnov } & \multicolumn{3}{l}{ Shapiro-Wilk } \\
\cline { 2 - 7 } Achievement & Statistic & df & Sig. & Statistic & df & Sig. \\
\cline { 2 - 7 } & Pretest of Experiment & .181 & 20 & .084 & .906 & 20 & .053 \\
& Pretest of Control & .141 & 22 & $.200^{*}$ & .944 & 22 & .234 \\
& Postest of Experiment & .160 & 20 & .193 & .907 & 20 & .057 \\
& Posttest of Control & .179 & 22 & .056 & .930 & 22 & .055 \\
\hline
\end{tabular}

Table 1 shows the result of normality test of student achievement. Based on it indicates that the data have normal.

Table 2. Independent Samples Test

\begin{tabular}{|c|c|c|c|c|c|c|c|c|c|c|}
\hline & & \multicolumn{9}{|c|}{$\begin{array}{l}\text { Levene's } \\
\text { Test for } \\
\text { Equality of } \\
\text { Variances t-test for Equality of Means }\end{array}$} \\
\hline & & & & & & Sig. (2 & Mean & $\begin{array}{l}\text { Std. Error } \\
\text { Differenc }\end{array}$ & $\begin{array}{l}95 \% \mathrm{C} \\
\text { Interval } \\
\text { Differe }\end{array}$ & $\begin{array}{l}\text { offidence } \\
\text { of the } \\
\text { nce }\end{array}$ \\
\hline & & $\mathrm{F}$ & Sig. & $\mathrm{t}$ & Df & tailed) & Difference & $\mathrm{e}$ & Lower & Upper \\
\hline \multirow[t]{2}{*}{ Achievement } & $\begin{array}{l}\text { Equal } \\
\text { variances } \\
\text { assumed }\end{array}$ & .000 & .983 & 2.633 & 40 & .012 & 15.509 & 5.891 & 3.603 & 27.415 \\
\hline & $\begin{array}{l}\text { Equal } \\
\text { variances } \\
\text { not } \\
\text { assumed }\end{array}$ & & & 2.635 & $\begin{array}{l}39.73 \\
4\end{array}$ & .012 & 15.509 & 5.886 & 3.610 & 27.409 \\
\hline
\end{tabular}

Table 2 summarizes the findings of a study that investigated the effect of a realistic mathematical approach on student achievement. This approach, according to the table, has an impact on data collection and presentation in fourth grade elementary school.

A realistic approach to mathematics, according to the findings, has an effect on learning achievement. These findings agree with those of Arnellis et al., who discovered that this method improves calculus learning [23].

Students should be given the opportunity to reinvent mathematics with the guidance of their teachers using this approach, and the reinvention of ideas and mathematics concepts should begin with the exploration of various situations and issues in the real world [24-25]. Lestari and Surya (2017), as well as Putri et al (2019). They also identify the contextual issue, solve it, compare and discuss the solution, and finally draw a conclusion. As a result, based on the principles and characteristics of RME, the following learning steps have been established: (1) 
identify the contextual issues; (2) solve the contextual problem; (3) compare and discuss the solutions; and (4) make a decision on the solution. [7-8][26-27]

\section{Conclusion}

The use of a realistic mathematical approach had an effect on student achievement. Students engage in a learning process that allows them to develop higher-order and contextual thinking skills through a series of stages.

\section{References}

[1] Amir, M. F., Fediyanto, N., Rudyanto, H. E., Nur Afifah, D. S., and Tortop, H. S. Elementary students' perceptions of 3Dmetric: A cross-sectional study. (2020). 6(6). https://doi.org/10.1016/j.heliyon.2020.e04052

[2] Rahayu, W., Putra, M. D. K., Iriyadi, D., Rahmawati, Y., and Koul, R. B. A Rasch and factor analysis of an Indonesian version of the Student Perception of Opportunity Competence Development (SPOCD) questionnaire. Cogent Education, (2020). 7(1). https://doi.org/10.1080/2331186X.2020.1721633

[3] Engelmann, C. A., and Huntoon, J. E. Improving student learning by addressing misconceptions. Eos, (2011). 92(50), 465-466. https://doi.org/10.1029/2011EO500001

[4] Santyasa, I. W., Warpala, I. W. S., and Tegeh, I. M. (2018). The Effect of Conceptual Change Model in the Senior High School Students' Understanding and Character in

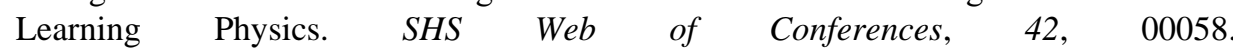
https://doi.org/10.1051/shsconf/20184200058

[5] Mees, M., Jay, T., and Habgood, J. Designing an adaptive learner model for a mathematics game. Proceedings of the European Conference on Games-Based Learning, 2018Octob(October), 800-807. (2018).

[6] Vosniadou, S., and Vamvakoussi, X. Examining mathematics learning from a conceptual change point of view: Implications for the design of learning environments. (2006). Instructional Psychology: Past, Present, and Future Trends: Sixteen Essays in Honour of Erik de Conte, 55-70. http://calteach.ucsc.edu/aboutus/documents/vosniadoumathlearningconcchg.pdf

[7] Laurens, T., Batlolona, F. A., Batlolona, J. R., and Leasa, M. How does realistic mathematics education (RME) improve students' mathematics cognitive achievement? Eurasia Journal of Mathematics, Science and Technology Education, (2018). 14(2), pp. 569-578. https://doi.org/10.12973/ejmste/76959

[8] Makonye, J. P. Teaching Functions Using a Realistic Mathematics Education Approach: A Theoretical Perspective. International Journal of Educational Sciences, (2014). 07(03). https://doi.org/10.31901/24566322.2014/07.03.27

[9] Mulbar, U., and Zaki, A. Design of Realistic Mathematics Education on Elementary School Students. Journal of Physics: Conference Series, (2018). 1028(1). https://doi.org/10.1088/1742-6596/1028/1/012155

[10] Akgun, S., and Kaya, E. How Do University Students Perceive the Nature of Science? Science and Education, (2020). 29(2), pp 299-330. https://doi.org/10.1007/s11191-02000105-x

[11] Park, W., Yang, S., \& Song, J. Eliciting students' understanding of nature of science with text-based tasks: insights from new Korean high school textbooks. International Journal of Science Education, (2020). 42(3), pp 426-450. https://doi.org/10.1080/09500693.2020.1714094 
[12] Siahaan, P., Dewi, E., and Suhendi, E. Introduction, Connection, Application, Reflection, and Extension (ICARE) Learning Model: The Impact on Students' Collaboration and Communication Skills. Jurnal Ilmiah Pendidikan Fisika Al-Biruni, (2020). 9(1), pp 109 119. https://doi.org/10.24042/jipfalbiruni.v9i1.5547

[13] Wahyudi, W., Waluya, S. B., Suyitno, H., and Isnarto, I. Schemata and creative thinking ability in cool-critical-creative-meaningful (3CM) learning. International Journal of Sustainability in Higher Education, (2020). 22(1), 1-28. https://doi.org/10.1108/IJSHE06-2019-0198

[14] Niiranen, S. Supporting the development of students' technological understanding in craft and technology education via the learning-by-doing approach. International Journal of Technology and Design Education, (2021). 31(1), 81-93. https://doi.org/10.1007/s10798-019-09546-0

[15] Furqani, D., Feranie, S., and Winarno, N. The Effect of Predict-Observe-Explain (POE) Strategy on Students' Conceptual Mastery and Critical Thinking in Learning Vibration and Wave. Journal of Science Learning, (2018). 2(1), 1. https://doi.org/10.17509/jsl.v2i1.12879

[16] Stephens, A. C., Fonger, N., Strachota, S., Isler, I., Blanton, M., Knuth, E., and Murphy Gardiner, A. A Learning Progression for Elementary Students' Functional Thinking. Mathematical Thinking and Learning, (2017). 19(3), 143-166. https://doi.org/10.1080/10986065.2017.1328636

[17] Todd, A., and Romine, W. The learning loss effect in genetics: What ideas do students retain or lose after instruction? CBE Life Sciences Education, (2018). 17(4), 1-12. https://doi.org/10.1187/cbe.16-10-0310

[18] Gönen, S. A study on student teachers' Misconceptions and scientifically acceptable conceptions about mass and gravity. Journal of Science Education and Technology, (2008). 17(1), 70-81. https://doi.org/10.1007/s10956-007-9083-1

[19] Kang, S., Scharmann, L. C., and Noh, T. Reexamining the role of cognitive conflict in science concept learning. Research in Science Education, (2004). 34(1), 71-96. https://doi.org/10.1023/B:RISE.0000021001.77568.b3

[20] Murphy, D. R. Effects of Explicit-Reflective Instruction on Preservice and Novice Teachers' Epistemic and Conceptual Change Mediated by Reasoning. ProQuest Dissertations and Theses, (2017). http://libproxy.usc.edu/login?url=https://search.proquest.com/docview/1960667379? accountid=14749\%0Ahttps://uscprimo.hosted.exlibrisgroup.com/openurl/01USC/01USC_SP?? url_ver=Z39.882004\&rft_val_fmt=info:ofi/fmt:kev:mtx:dissertation\&genre=dissertations $+\&+\mathrm{t}$

[21] Dai, R., Fritchman, J. C., Liu, Q., Xiao, Y., Yu, H., and Bao, L. Assessment of student understanding on light interference. Physical Review Physics Education Research, (2019). 15(2), 20134. https://doi.org/10.1103/PhysRevPhysEducRes.15.020134

[22] Sudarsana, I. K., Renawati, P. W., Nerta, I. W., Poniman, P., Arta Widana, I. K., Saddhono, K., and Napitupulu, D. The Effectiveness of Multimedia Training for Elementary School Teachers in Karangasem, Bali. Journal of Physics: Conference Series, (2018). 1114(1). https://doi.org/10.1088/1742-6596/1114/1/012032

[23] Arnellis, A., Fauzan, A., Arnawa, I. M., and Yerizon, Y. The Effect of Realistic Mathematics Education Approach Oriented Higher Order Thinking Skills to Achievements' Calculus. Journal of Physics: Conference Series, (2020). 1554(1). https://doi.org/10.1088/1742-6596/1554/1/012033 
[24] Lestari, L., \& Surya, E. The Effectiveness of Realistic Mathematics Education Approach on Ability of Students' Mathematical Concept Understanding. International Journal of Sciences: Basic and Applied Research, (2017). 34(1), 91-100. http://gssrr.org/index.php?journal=JournalOfBasicAndApplied

[25] Putri SK. Development of Learning Devices Based on Realistic Mathematics Education to Improve Students' Spatial Ability and Motivation. International Electronic Journal of Mathematics Education. 2019;14(2):393-400.

[26] Dickinson P, Eade F, Gough S, Hough S. Using Realistic Mathematics Education with low to middle attaining pupils in secondary schools. InProceedings of the British Congress for Mathematics Education 2010 (Vol. 5, No. 1, pp. 34-46).

[27] Julie C, Gierdien F. Reflections on Realistic Mathematics Education from a South African Perspective. InInternational Reflections on the Netherlands Didactics of Mathematics 2020 (pp. 71-82). Springer, Cham. 